\title{
MODELING OF FUEL CONSUMPTION FOR FOREST TRANSPORTATION ${ }^{1}$
}

\author{
POMPEU PAES GUIMARÃES ${ }^{2, *}$, JULIO EDUARDO ARCE ${ }^{3}$, EDUARDO DA SILVA LOPES ${ }^{4}$, ALLAN LIBANIO \\ PELISSARI $^{3}$, GABRIELA SALAMI $^{2}$, VINICIUS GOMES DE CASTRO $^{2}$
}

\begin{abstract}
As fuel costs increase, it is essential to take measures involving planning and control on any activities with high consumption. Thus, the main aim of this work was modeling the fuel consumption of forest road transportation by truck. We collected data about time, driving distance, average speed, fuel consumption and the load carried by the vehicle for loaded trips, unloaded trips, and the total cycle of forest transport in regions between the municipality of Campo do Tenente (forest site) and Piên (factory) located in Paraná state, Brazil. The Pearson's correlation was used to determine the relationship between variables, while the Stepwise procedure was used to generate regression equations to estimate fuel consumption. The highest correlations were found between fuel consumption and driving distance, average speed and liquid weight of the load; also, there was a significant correlation between driving distance and average speed. Adjusted equations were statistically adequate to estimate fuel consumption based on driving distance, liquid weight of the load, average speed and duration time for loaded trips, unloaded trips and the total forest road transportation cycle.
\end{abstract}

Keywords: Logistics; Planning; Wood supply

\section{MODELAGEM DO CONSUMO DE COMBUSTÍVEL DO TRASPORTE FLORESTAL}

RESUMO - Com o aumento nos custos dos combustíveis, é fundamental atuar em medidas que envolvam o planejamento e o controle nas atividades com consumo elevado. Dessa forma, objetivou-se modelar o consumo de combustível da carreta utilizada no transporte rodoviário florestal. Para isso, dados de duração, distância percorrida, velocidade média, consumo de combustível e carga transportada pelos veículos nas operações das viagens carregado, vazio e ciclo total foram coletados nas regiões de Campo do Tenente (planta florestal) a Piên (planta industrial) no estado do Paraná. A correlação linear de Pearson foi utilizada para determinar a relação entre as variáveis, ao passo que o procedimento Stepwise foi empregado para compor as equações de regressão na estimativa do consumo de combustível. As maiores correlações foram observadas entre a distância percorrida, carga líquida e velocidade média com o consumo de combustível; ocorrendo, também, correlações significativas entre a distância percorrida e a velocidade média. As equações ajustadas foram estatisticamente adequadas para estimar o consumo de combustível em função da distância percorrida, da carga líquida transportada, da velocidade média e da duração nas viagens carregado, vazio e ciclo total de transporte rodoviário florestal.

Palavras-chave: Logística. Planejamento. Abastecimento florestal.

\footnotetext{
${ }^{*}$ Corresponding Author

${ }^{1}$ Received for publication in $11 / 10 / 2014$; accepted in $12 / 16 / 2015$.

${ }^{2}$ Departament of Vegetable Sciences, Universidade Federal Rural do Semi-Árido, Mossoró, RN, Brazil; pompeu.guimaraes@ufersa.edu.br, gabriela.salami@ufersa.edu.br, vinicius.castro@ufersa.edu.br.

${ }_{3}^{3}$ Departament of Forest Science, Universidade Federal do Paraná, Curitiba, PR, Brazil; jarce@ufpr.br, allanpelissari@gmail.com.

${ }^{4}$ Departament of Forest Engineering, UNICENTRO, Irati, PR, Brazil; eslopes@irati.unicentro.br.
} 


\section{INTRODUCTION}

The estimated gross value of annual Brazilian forest sector production was $\mathrm{R} \$ 53.3$ billion in 2013, and around $\mathrm{R} \$ 2$ billion has been invested on harvesting and forest transportation (ABRAF, 2013). A tendency in wood supply chain logistics is to place factories as close as possible to the consumer market if the final product transportation cost is higher than the raw material transportation cost (MACHADO et al., 2009). Thus, it is essential to understand all the different factors that affect the transportation cost before taking management decisions. Braga et al. (2011) studied the cost of transportation by Bitrem (i.e. tractor truck and two trailers) and concluded that the factors impacting road costs are, mainly, fuel, oil, filters, maintenance, toll and wheel set.

As the fuel price increases, it becomes essential to take measures that consider planning and control in activities with high fuel consumption. Factors that can be improved are wood transportation time and energy efficiency, especially if there are options of roads with better pavement condition (SILVEIRA et al. 2004; BARTHOLOMEU and CAIXETA FILHO, 2008).

Some studies aimed to determine the fuel consumption in vehicles used in forest road transportation, e.g. Silveira et al. (2004), Holzleitner et al. (2011) and Klvac et al. (2013). In Brazil, such works are based on estimated average consumption of the vehicles and fuel price at the specific moment, like the studies developed by Freitas et al. (2004), Morais (2012) and Alves et al. (2013).

Based on dates of an independent producer that wanted to implement a reforestation project and deliver the wood direct to the factory, Silva et al. (2007) established, by economic criteria, the maximum transport distance for different vehicles as $226 \mathrm{~km}$ for Rodotrem (i.e. a truck with two large trailers) and as $155 \mathrm{~km}$ for small trucks.

Furthermore, Arce et al. (1999) proposed a transportation scheduling system for forest multiproducts, with the objective of minimizing the transport cost paid to the forest companies, considering production aspects, clients and products. Klan et al. (2010) pointed out driving distance, the type of traffic and routes, transport region, vehicle size and imbalance between loaded and unloaded trips, as factors that can significantly influence the variation of cost and cargo road transportation composition.

Thus, the aim of this work was mathematical modeling of fuel consumption in the forest road transport sector, using truck, considering the hypothesis that the variables of duration time, driving distance, average speed and liquid weight of transported wood are able to estimate statistically the fuel consumption in a satisfactory way.

\section{MATERIAL AND METHODS}

The data were collected in a forest industry located in the southern part of Paraná state, Brazil, where the forest road transportation took place using two different routes between the municipalities of Campo do Tenente (forest site) and Piên (factory), as shown in Figure 1.

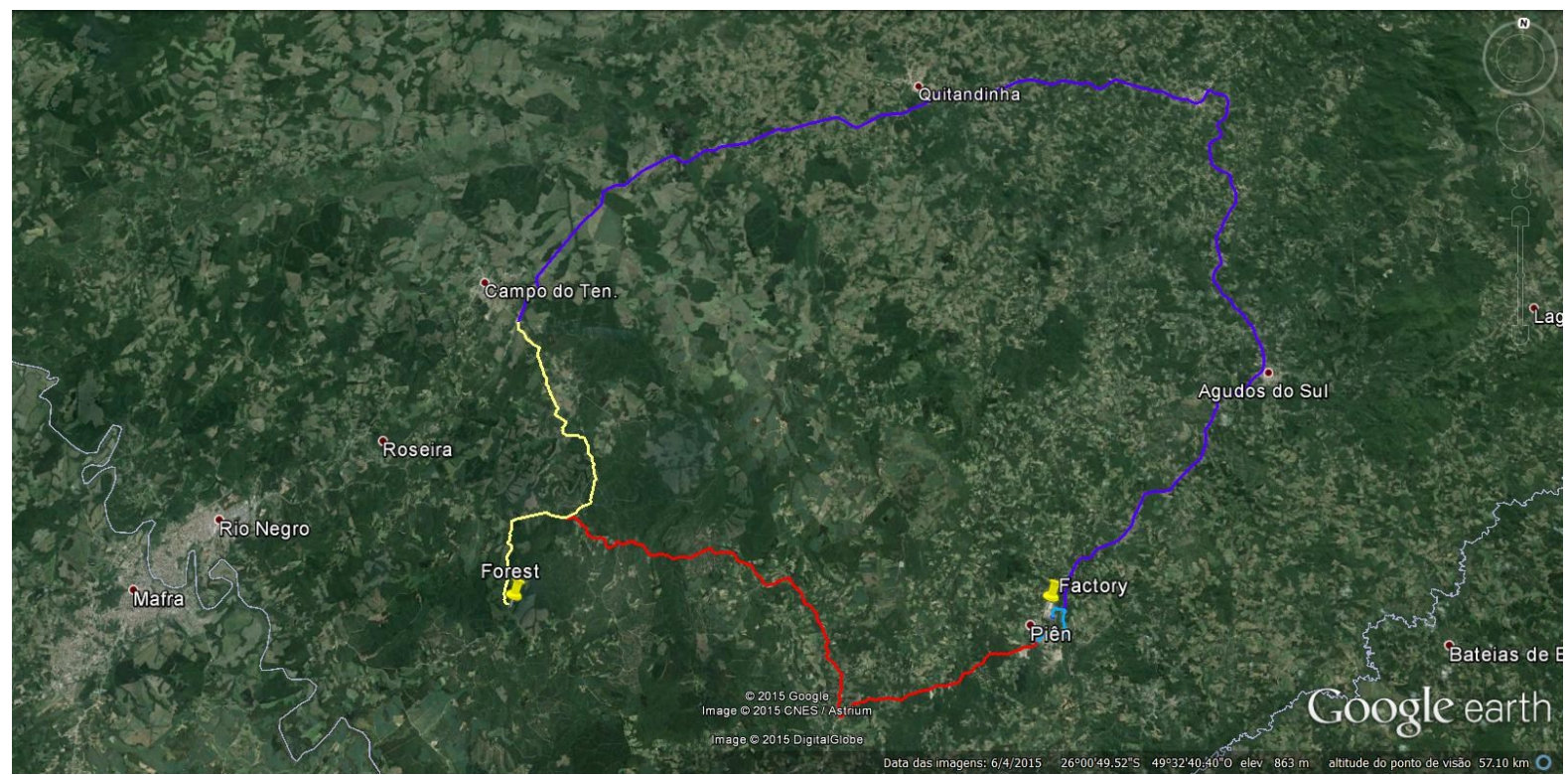

Figure 1. Routes of forest road transportation. From: Google Earth (2014). 
The length of the routes between forest site and industry are detailed in Table 1 . The first route, related to the loaded vehicle trip, was $89.3 \mathrm{~km}$ long, where $3.1 \%$ was asphalt, represented in Figure 1 by the purple and blue color roads, and part of the yellow color road. The route represented by the blue color was related to part of the road with an asphalt coating $(3.5 \mathrm{~km})$. The second route was used when the vehicle was unloaded, and was $44.1 \mathrm{~km}$ long, where $7.7 \%$ was asphalt, represented by the red color road and part of the yellow color road.

Table 1. Elevation profile of the routes

\begin{tabular}{cccccc}
\hline \multirow{2}{*}{ Routes } & \multirow{2}{*}{ Distance $(\mathrm{km})$} & \multicolumn{2}{c}{ Altitude $(\mathrm{m})$} & \multicolumn{2}{c}{ Maximum slope (\%) } \\
\cline { 3 - 5 } & & Minimum & Maximum & Uphill & Downhill \\
\hline Blue & 3.4 & 826.0 & 857.0 & 10.4 & 10.4 \\
Purple & 71.6 & 805.0 & 929.0 & 10.0 & 16.6 \\
Yellow & 17.9 & 806.0 & 914.0 & 28.0 & 21.3 \\
Red & 34.2 & 812.0 & 921.0 & 16.8 & 9.0 \\
\hline
\end{tabular}

The industrial object of this work is the cultivation of trees of Pinus genus, with an emphasis on Pinus taeda plantation with initial spacing of 1.6 trees per hectare, without thinning and clear cut at 15 years of age, and an estimated average production of $40 \mathrm{~m}^{3} \mathrm{ha}^{-1}$ year ${ }^{-1}$; the supply management aims, basically, at processed wood for industry and logs for the local market.

Forest harvesting consists of tree harvesting activity and $\log$ extraction to the roadside. The harvesting system used in the Campo do Tenente region was for short logs $(2.6 \mathrm{~m}$ long and diameter
8-18 cm), using harvesters for felling and processing, and forwarder for log extraction. The forest company used a harvesting system where logs (with bark and air drying on the field) were stoked for three months before transportation.

The forest road transportation was conducted by a Mercedes Benz tractor-truck, model AXOR3344S (33 ton of total gross weight and 440 $\mathrm{HP}$ ), with two rear axles and $6 \times 4$ traction, manufactured in 2012 (Table 2) attached to a semitrailer, with loaded weight of 48.5 metric tonnes.

Table 2. AXOR 3344S Model specifications.

\begin{tabular}{lll}
\hline Engine & Output & $323 \mathrm{~kW}(439 \mathrm{hp})-1.900 \mathrm{rpm}$ \\
& Torque & $2,150 \mathrm{Nm}(219.2 \mathrm{mkgf})-1.100 \mathrm{rpm}$ \\
& Total displacement & $11.967 \mathrm{~cm}^{3}$ \\
\hline Transmission & PTO & MB NA $121-1 \mathrm{~b}$ \\
& Type & Powershift constant mesh automated manual gearbox \\
& Clutch & Double plate clutch, diameter $400 \mathrm{~mm}$ \\
& Ratios $\left(1^{\text {st }}\right.$ gear $/ 12^{\text {th }}$ gear $)$ & $11.72 / 0.69$ \\
\hline
\end{tabular}

The dates that the forest road transportation was collected were from $11 / 07 / 2012$ to $02 / 22 / 2013$.

The meteorological data referring to 2012 and 2013 are shown in Figure 2.

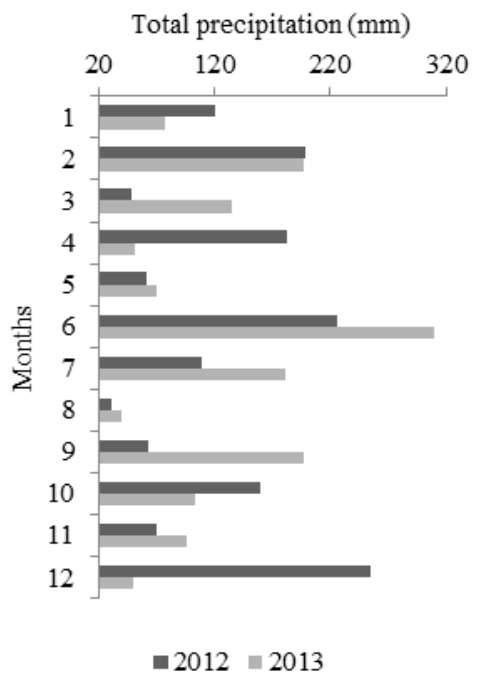

(A)

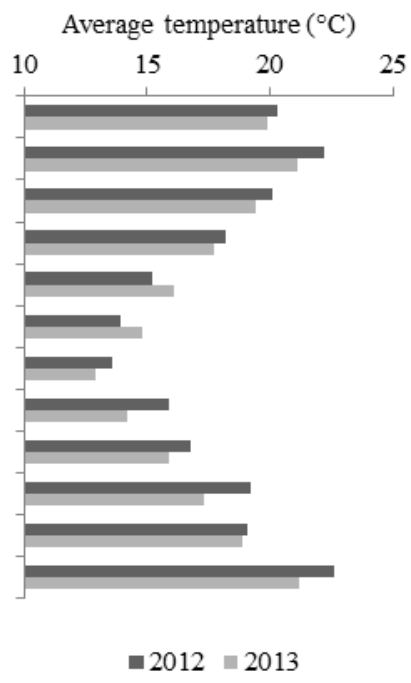

(B)

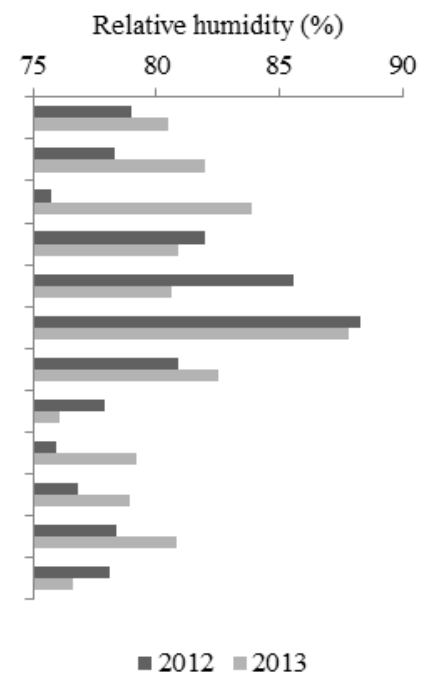

(C)

Figure 2. Meteorological data of the study region: (A) total precipitation (mm); (B) average temperature $\left({ }^{\circ} \mathrm{C}\right)$; and $(\mathrm{C})$ relative humidity $(\%)$.

From: INMET (2014) 
Regarding the total precipitation during the experimental period, there was an average precipitation of $151.8 \mathrm{~mm}$. The average relative humidity was around $80.0 \%$. The average temperatures for 2012 and 2013 were similar: respectively, 18.1 and $17.4^{\circ} \mathrm{C}$. During the data collection period, the average temperature was $20.4^{\circ} \mathrm{C}$ (Table 3 ).

Table 3. Meteorological data collection between 11/07/2012 and 02/22/2013.

$\begin{array}{cc}\text { Average precipitation }(\mathrm{mm}) & 5.3 \\ \text { Maximum precipitation }(\mathrm{mm}) & 66.3 \\ \text { Total precipitation }(\mathrm{mm}) & 567.5 \\ \text { Average temperature }\left({ }^{\circ} \mathrm{C}\right) & 20.8 \\ \text { Average } \mathrm{RH}(\%) & 79.7\end{array}$

From: INMET (2014).

The total transportation cycle was composed of four work phases: displacement and loading, loaded trip, unloading and unloaded trip:

(a) Displacement and loading - the operation starts at the arrival of vehicle to the safehouse of the forest site, followed by the displacement to the loading spots, loading logs at the load compartment of the vehicle, securing load and returning to the safehouse for manual cargo measurement and issue of the invoice;

(b) Loaded trip - displacement of the forest road transportation vehicle, from the forest site safehouse to the factory gate;

(c) Unloading - composed of the steps of preregistering and weighing, displacement to the unloading spot, unloading logs from the load compartment of the vehicle and stocking at the yard, cleaning the vehicle load compartment, returning to the industry gate and vehicle weighing;

(d) Unloaded trip - displacement of the empty vehicle, from the gates of the industry to the safehouse of the forest site.

Sample size and minimum number of repetition of transportation cycles used in this study were established by the equation suggested by Conaw (1977):

$$
n \geq \frac{t^{2} * s^{2}}{e^{2}}
$$

Where: $\mathrm{n}=$ number of required samples; $\mathrm{t}=$ tabulated value at $5 \%$ of probability (Student's $t$ value); $\mathrm{s}=$ sample standard deviation; and $\mathrm{e}=$ tolerable error of $5 \%$.

The forest loader was composed of a basemachine of a track hydraulic crawler excavator, Caterpillar model CAT312DL, engine 3054C, output of $90.0 \mathrm{HP}$, equipped with a Timber Forest grapple, with load area capacity of $0.8 \mathrm{~m}^{2}$ and average reach of $9.0 \mathrm{~m}$.

The industry log unloader was composed of a base-machine of a track hydraulic crawler excavator, Volvo model EC210, output of 143 HP, equipped with a $J$ de Souza grapple, with load area capacity of $1.35 \mathrm{~m}^{2}$ and average reach of $10.8 \mathrm{~m}$.

Data referring to: a) each operation time (min); b) driving distance ( $\mathrm{km}$ ) for each operation; c) average speed $(\mathrm{km} / \mathrm{h})$ for each trip; and d) fuel consumption (l) were collected and stored by a telemetry system installed in one truck.

Based on the records of exit times recorded at the forest site safehouse and industry gate, it was possible to determine the time required for each operation. Data from the liquid weight transported in each cycle were made available by the company from the difference between the loaded vehicle weight and the empty vehicle weight.

Pearson's linear correlation was used to determine the relationship between the variables, indicated by values between \pm 1 . Values equal to zero represented a lack of linear correlation; values lower than 0.3 indicated a weak correlation; between 0.3 and 0.7 , a moderate correlation; and values higher than 0.7, a strong correlation (PELISSARI, 2012). The coefficient was submitted to a Student's t-test, at $5 \%$ probability, to determine the significance.

The step-by-step variable selection Stepwise method was used to compare the regression equations. During this procedure, the independent variables' partial correlation was tested, when they were individually included or excluded from a mathematical model, aiming to estimate the dependent variable (SCOLFORO, 2005).

The procedure was realized by SAS 9.0 software (SAS INSTITUTE, 2008). Thus, arithmetic and logarithmic equations were determined with the intention of selecting the one that best estimated the fuel consumption of the truck.

The following variables used to generate the equations were independent: each operation cycle time, driving distance, average speed and liquid weight of the transported load in their original, inverse, combined, square and logarithmic form. The fuel consumption in its original and logarithmic form was dependent (Table 4). 
P. P. GUIMARÃES et al.

Table 4. Variables used to adjust the equations to estimate the fuel consumption of forest road transportation

\begin{tabular}{clcccccc}
\hline Variable & \multicolumn{1}{c}{ Note } & Variable & Note & Variable & Note & Variable & Note \\
\hline y & $C$ & $\mathrm{x} 6$ & $D \cdot V$ & $\mathrm{x} 13$ & $Q \cdot M$ & $\mathrm{x} 20$ & $1 / M$ \\
$\mathrm{y} 1$ & $\log (C)$ & $\mathrm{x} 7$ & $D \cdot M$ & $\mathrm{x} 14$ & $V$ & $\mathrm{x} 21$ & $M^{2}$ \\
$\mathrm{x} 1$ & $D$ & $\mathrm{x} 8$ & $Q$ & $\mathrm{x} 15$ & $1 / V$ & $\mathrm{x} 22$ & $\log (M)$ \\
$\mathrm{x} 2$ & $1 / D$ & $\mathrm{x} 9$ & $1 / Q$ & $\mathrm{x} 16$ & $V$ & $\mathrm{x} 23$ & $\sqrt{D}$ \\
$\mathrm{x} 3$ & $D^{2}$ & $\mathrm{x} 10$ & $Q^{2}$ & $\mathrm{x} 17$ & $\log (V)$ & $\mathrm{x} 24$ & $\sqrt{Q}$ \\
$\mathrm{x} 4$ & $\log (D)$ & $\mathrm{x} 11$ & $\log (Q)$ & $\mathrm{x} 18$ & $V . M$ & $\mathrm{x} 25$ & $\sqrt{V}$ \\
$\mathrm{x} 5$ & $D \cdot Q$ & $\mathrm{x} 12$ & $Q \cdot V$ & $\mathrm{x} 19$ & $M$ & $\mathrm{x} 26$ & $\sqrt{M}$ \\
\hline
\end{tabular}

The precision of the estimated variables was determined by the coefficient of determination $\left(R^{2}\right)$, adjusted coefficient of determination $\left(R_{a j}^{2}\right)$, standard error of the estimative in percentage $\left(S_{y x(\%)}\right)$ and graphics' analysis of residues.

The standard error of the estimative expressed how far, in term of averages, the estimated values were from their respective observed values. The closer the error was from zero, the more efficient was the regression. If the dependent variable changed somehow, the $S_{y x}$ was transformed again, and the estimated dependent variables were

recalculated into the observed variable unit (RIBEIRO, 2012).

\section{RESULTS AND DISCUSSION}

The number of transportation cycle required for a better intensity of sampling was calculated and is shown in Table 5. The minimum number of cycles required was 41.22. We collected information for 107 cycles using one truck aiming at fuel consumption characterization.

Table 5. Number of transportation cycles collected with one truck.

\begin{tabular}{cccc}
\hline Ttab & 1.98 & Minimum Cycles & 41.22 \\
Standard deviation & 17.64 & Collected Cycles & 107.00 \\
Averege & 108.77 & & \\
\hline
\end{tabular}

Ttab $=$ Tabulated Student's $\mathrm{t}-$ value .

The total transportation time (i.e. displacement and loading, unloading, loaded trip and unloaded trip) was high (Table 6), an average time of 634 minutes per cycle. Thus, if the cycle time was reduced, more trips could be made during working hours, through minimizing the activities with stationary vehicles.

The longest period of the total transportation time was related to the long time spent during the work phase of displacement and loading. The bottleneck operation was displacement and loading, which is why it is necessary promote training and recycling to improve those operations and logistics to reduce lines, stops and mechanical breaks that tend to increase the forest road transportation cycle time. However, to be able to understand fully the reason for this long duration, it is necessary to develop a future specific study of times and movements of all activities.

During the phases of displacement and loading and unloading, the vehicle fuel consumption occurred when there was displacement from the safehouse of the forest site or the industry gate to the loading or unloading operation spot, respectively. Most of the time during those phases, the vehicle was stationary, with only the forest loader or unloader being used.

The long period of displacement and loading (258.6 $\mathrm{min}$ ) can be explained by long distance between the safehouse and the loading spot, mechanical breaks of heavy and extra-heavy vehicles near to the forest site, which made the maintenance and towing difficult, and rain when the vehicles were stuck, leaving a vehicle jam at the loading site and forcing the driver to wait in a queue. Those variables were responsible for the high value of the coefficient of variation found for this operation. As a consequence, it is difficult to elaborate a loading plan; a large part of the forest road transportation time is spent in passive activities (i.e. loading).

Unloading, due the fact that it happened at the factory, had better time control than loading. During unloading, the truck took an average of 118.3 minutes, including weighing time, displacement to the unloading spot, lines, maneuvers, cleaning, empty weighing and displacement back to the gate.

During loading or unloading, the average speed of the trucks was very slow, as most of the time they were stationary. 
Table 6. Descriptive statistics of forest road transportation.

\begin{tabular}{|c|c|c|c|c|}
\hline & & Average & Standard deviation & $\mathrm{CV}(\%)$ \\
\hline \multirow{5}{*}{$\begin{array}{l}\text { Displacement and } \\
\text { loading }\end{array}$} & $\mathrm{D}$ & 258.6 & 376.7 & 145.6 \\
\hline & Q & 19.3 & 10.0 & 51.8 \\
\hline & $\mathrm{C}$ & 20.0 & 7.5 & 37.8 \\
\hline & $\mathrm{V}$ & 16.6 & 4.5 & 27.0 \\
\hline & M & $34,433.5$ & $4,119.8$ & 12.0 \\
\hline \multirow{5}{*}{ Unloading } & $\mathrm{D}$ & 118.3 & 51.3 & 43.3 \\
\hline & $\mathrm{Q}$ & 1.4 & 0.3 & 20.2 \\
\hline & $\mathrm{C}$ & 2.8 & 1.1 & 40.6 \\
\hline & $\mathrm{V}$ & 3.0 & 3.4 & 110.1 \\
\hline & $\mathrm{M}$ & $34,433.5$ & $4,119.8$ & 12.0 \\
\hline \multirow{5}{*}{ Loaded trip } & $\mathrm{D}$ & 157.6 & 109.8 & 69.7 \\
\hline & $\mathrm{Q}$ & 72.6 & 15.1 & 20.8 \\
\hline & $\mathrm{C}$ & 56.9 & 8.8 & 15.5 \\
\hline & $\mathrm{V}$ & 40.0 & 10.3 & 25.7 \\
\hline & $\mathrm{M}$ & $34,433.5$ & $4,119.8$ & 12.0 \\
\hline \multirow{5}{*}{ Unloaded trip } & $\mathrm{D}$ & 97.2 & 85.3 & 87.8 \\
\hline & $\mathrm{Q}$ & 52.5 & 17.9 & 34.0 \\
\hline & $\mathrm{C}$ & 28.2 & 9.4 & 33.5 \\
\hline & $\mathrm{V}$ & 49.4 & 18.4 & 37.2 \\
\hline & M & - & - & - \\
\hline \multirow{5}{*}{ Total cycle } & $\mathrm{D}$ & 634.0 & 391.6 & 61.8 \\
\hline & $\mathrm{Q}$ & 147.0 & 30.2 & 20.5 \\
\hline & $\mathrm{C}$ & 108.8 & 17.6 & 16.2 \\
\hline & $\mathrm{V}$ & 24.4 & 6.3 & 25.7 \\
\hline & $\mathrm{M}$ & $34,433.5$ & $4,119.8$ & 12.0 \\
\hline
\end{tabular}

The loaded truck ran a $27 \%$ longer distance, was $18.8 \%$ slower, took $38.3 \%$ longer time and had $50.4 \%$ higher fuel consumption compared to the unloaded truck.

The empty vehicle reached an average speed of $49.4 \mathrm{~km} \mathrm{~h}^{-1}$ and drove a shorter distance than loaded trips, an average of $52.5 \mathrm{~km}$ (Table 6), once the empty vehicle could drive over alternative routes. Nurminen and Heinonen (2007) also demonstrated that the average distance driven by loaded vehicles $(68.0 \mathrm{~km})$ was higher than that of empty vehicles $(33.0 \mathrm{~km})$.

The average speed of the total transportation cycle was slow $\left(24.4 \mathrm{~km} \mathrm{~h}^{-1}\right)$, due to loading and unloading operations. Considering that the speed is associated with the most part of serious accidents, the following speed limits are imposed for wood transportation: $80 \mathrm{~km} \mathrm{~h}^{-1}$ for asphalted roads in dry conditions; $60 \mathrm{~km} \mathrm{~h}^{-1}$ for asphalted roads in wet conditions; and $30 \mathrm{~km} \mathrm{~h}^{-1}$ for roads without asphalt or with loading in the field (FIBRIA, 2012).
Analyzing the road transportation of round wood with six trucks in Austria, Holzleitner et al. (2011) reported that when an average distance of 51 $\mathrm{km}$ (from 27 to $102 \mathrm{~km}$ ) was driven, the average fuel consumption was $0.77 \mathrm{l} \mathrm{km}^{-1}\left(0.32 \mathrm{l} \mathrm{km}^{-1}\right.$ for unloaded trips and $1.021 \mathrm{~km}^{-1}$ for loaded trips).

Fuel consumption of the analyzed truck was $0.741 \mathrm{~km}^{-1}\left(0.531 \mathrm{~km}^{-1}\right.$ for unloaded trips and 0.781 $\mathrm{km}^{-1}$ for loaded trips). If the results are compared to those reported by Holzeitner et al. (2011), it can be noticed that the total cycle fuel consumption was similar; however there was a higher consumption for unloaded trips and a lower consumption for loaded trips.

The total transportation cycle took 634 minutes. During working hours with two drivers, 2.3 loaded trips were delivered. Considering the coefficient of variation of $61.8 \%$, the truck's fuel consumption was recorded as function of the average, minimum and maximum transport cycle number, as shown in Table 7.

Table 7. Fuel consumption per minimum, average and maximum transport cycle number.

\begin{tabular}{ccccc}
\hline & Time (min) & $\begin{array}{c}\text { Number of } \\
\text { transportation } \\
\text { cycles }\end{array}$ & $\begin{array}{c}\text { Trasported wood } \\
(\mathrm{kg})\end{array}$ & $\begin{array}{c}\text { Driving distance } \\
(\mathrm{km})\end{array}$ \\
\hline Minimum & 242.18 & 5.9 & $203,157.65$ & $2,512.23$ \\
Average & 634.0 & 2.3 & $79,197.05$ & $1,552.32$ \\
Maximum & 1025.8 & 1.4 & $48,206.9$ & 541.92 \\
\hline
\end{tabular}

If there is a reduction in the total transportation cycle time, it is possible to increase the number of trips in the 24 working hours to 3.6 , even with an increase of fuel consumption per cycle,
$61.1 \%$ more wood would be delivered to the final destination.

In order to estimate the fuel consumption for loaded trips, unloaded trips and total transportation 
cycles with one truck, the correlation between variables involved at the process was evaluated
(Table 8). Displacement and loading and unloading operations were included in the variable total cycle.

Table 8. Correlation between forest road transportation variables.

\begin{tabular}{|c|c|c|c|c|c|c|}
\hline & & $\mathrm{D}$ & $Q$ & $\mathrm{C}$ & $\mathrm{V}$ & $\bar{M}$ \\
\hline \multirow{5}{*}{ Loaded trip } & $\mathrm{D}$ & 1 & & & & \\
\hline & Q & $0.2484 *$ & 1 & & & \\
\hline & $\mathrm{C}$ & $0.2927 *$ & $0.8559 *$ & 1 & & \\
\hline & V & $-0.1982 *$ & $0.4664 *$ & $0.2270 *$ & 1 & \\
\hline & M & $0.0248^{\mathrm{ns}}$ & $-0.0510^{\mathrm{ns}}$ & $0.1836^{\mathrm{ns}}$ & $-0.1847^{\mathrm{ns}}$ & 1 \\
\hline \multirow{5}{*}{ Unloaded trip } & $\mathrm{D}$ & 1 & & & & - \\
\hline & $\mathrm{Q}$ & $0.0718^{\mathrm{ns}}$ & 1 & & & - \\
\hline & $\mathrm{C}$ & $0.1254^{\mathrm{ns}}$ & $0.9460 *$ & 1 & & - \\
\hline & $\mathrm{V}$ & $-0.2037 *$ & $0.5907 *$ & $0.4332 *$ & 1 & - \\
\hline & M & - & - & - & - & - \\
\hline \multirow{5}{*}{ Total cycle } & $\mathrm{D}$ & 1 & & & & \\
\hline & Q & $0.1643^{\mathrm{ns}}$ & 1 & & & \\
\hline & $\mathrm{C}$ & $0.2455 *$ & $0.9246 *$ & 1 & & \\
\hline & V & $-0.0918^{\mathrm{ns}}$ & $0.4524 *$ & $0.2842 *$ & 1 & \\
\hline & $\mathrm{M}$ & $0.0253^{\mathrm{ns}}$ & $-0.0996^{\mathrm{ns}}$ & $0.1029^{\mathrm{ns}}$ & $-0.2106 *$ & 1 \\
\hline
\end{tabular}

Where: $\mathrm{D}=$ Time $(\mathrm{min}) ; \mathrm{Q}=$ Driving distance $(\mathrm{km}) ; \mathrm{C}=$ Consumption $(\mathrm{l}) ; \mathrm{V}=$ Average speed $\left(\mathrm{km} \mathrm{h}^{-1}\right)$; e $\mathrm{M}=$ liquid weight $(\mathrm{kg})$.

$*=$ significant at $5 \%$ probability by Student's $\mathrm{t}$ test; $\mathrm{e}^{\mathrm{ns}}=$ not significant.

All work phases (unloaded trip, loaded trip and total cycle) presented a strong correlation between driving distance and fuel consumption, showing a direct relationship between them, as was expected because distance is one of the main factors that contributes to the transportation cost.

Other factors had a moderate correlation for unloaded trips, loaded trips and total cycles. Driving distance and average speed presented a direct relation, where faster average speed was recorded on higher distance values.

Fuel consumption presented a moderate correlation with average speed during unloaded trips, and a weak correlation during loaded trips or total cycles. As the average speed values increase, higher fuel consumption values were found.

Loaded trip duration time was weakly correlated with the driving distance, fuel consumption (directly) and average speed (inversely). Higher driving distance and fuel consumption values were observed for trips that took longer, the same as that observed by Leite et al. (1993). However the correlation between unloaded trip duration and truck speed was inversely proportional. The faster the truck accelerated, the quicker the unloaded trip was.

There was a weak correlation between time and fuel consumption for total transport cycle, although at longer total cycles, fuel consumption was higher. A weak correlation was observed between average speed and liquid weight transported, the average speed tending to be lower as the load became heavier. The regression models were analyzed by the Stepwise method to adjust the original and logarithmic equations to estimate fuel consumption based on driving distance, average speed, liquid weight and time (Table 9).

The equations to estimate fuel consumption presented good adjustments for the independent variables recorded by the telemetric system.

After $S_{y x(\%)}$ (which measures the dispersion among the observed and estimated fuel consumption values) was analyzed, the original equation for the loaded trip was chosen due to the lower dispersion values than the estimated line. The adjusted equation presented $R_{a j(\%)}^{2}$ values higher than $90 \%$ and $S_{y x(\%)}$ between 4.58 and $9.73 \% . \quad R^{2} a j(\%)$ values were higher than those reported by Klvac et al. (2013) of $43.9 \%$; besides, estimating fuel consumption for total transportation cycle, unloaded and loaded trips.

The best adjustment occurred for the total transportation cycle. However, an estimate of the adjusted equation of fuel consumption based on independent variables was satisfactory, which confirmed the results found for correlations, where driving distance showed a higher correlation with the adjusted models to estimate fuel consumption. 
Table 9. Adjusted equations for forest road transportation using a truck.

\begin{tabular}{|c|c|c|}
\hline \multirow{2}{*}{ 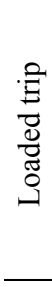 } & $\begin{array}{c}C=\beta_{0}+\beta_{1} * Q^{-1}+\beta_{2} * Q^{2}+\beta_{3} * M^{2} \\
R_{a j(\%)}^{2}=90.38 S_{y x(\%)}=4.64\end{array}$ & $\begin{array}{l}\beta_{0}=-31.8856 \beta_{1}=1.65 * 10^{3} \\
\beta_{2}=1.01 * 10^{-2} \beta_{3}=7.01 * 10^{-9}\end{array}$ \\
\hline & $\begin{array}{c}\ln C=\beta_{0}+\beta_{1} * Q^{-1}+\beta_{2} * \ln Q+\beta_{3} * M^{-1} \\
R_{a j(\%)}^{2}=90.38 S_{y x(\%)}=4.84\end{array}$ & $\begin{array}{c}\beta_{0}=-14.4285 \beta_{1}=1.58 * 10^{2} \\
\beta_{2}=3.7502 \beta_{3}=1.22 * 10^{-10}\end{array}$ \\
\hline \multirow{2}{*}{ 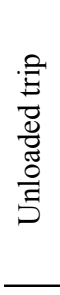 } & $\begin{array}{c}C=\beta_{0}+\beta_{1} * Q+\beta_{2} * V^{-1} \\
R_{a j(\%)}^{2}=91.96 S_{y x(\%)}=9.53\end{array}$ & $\beta_{0}=-6.4854 \beta_{1}=0.5626 \beta_{2}=1.97 * 10^{-2}$ \\
\hline & $\begin{array}{c}\ln C=\beta_{0}+\beta_{1} * Q+\beta_{2} * Q^{2}+\beta_{3} * V^{-1} \\
R_{a j(\%)}^{2}=91.63 S_{y x(\%)}=9.73\end{array}$ & $\begin{array}{c}\beta_{0}=1.8327 \beta_{1}=3.04 * 10^{-2} \\
\beta_{2}=-1.00 * 10^{-4} \beta_{3}=6.4517\end{array}$ \\
\hline \multirow{2}{*}{$\begin{array}{l}\frac{0}{0} \\
\frac{0}{0} \\
\frac{\pi}{0} \\
\stackrel{0}{0}\end{array}$} & $\begin{array}{c}C=\beta_{0}+\beta_{1}^{*} D^{-1}+\beta_{2} * Q^{2}+\beta_{3} * Q^{*} M+\beta_{4} * V^{-1} \\
R_{a j(\%)}^{2}=92.10 S_{y x(\%)}=4.58\end{array}$ & $\begin{array}{c}\beta_{0}=54.8072 \beta_{1}=-2.47 * 10^{-3} \\
\beta_{2}=1.17 * 10^{-3} \beta_{3}=5.57 * 10^{-6} \\
\beta_{4}=90.7373\end{array}$ \\
\hline & $\begin{array}{c}\ln C=\beta_{0}+\beta_{1} * D^{-1}+\beta_{2} * Q+\beta_{3} * V^{-1}+\beta_{4} * M^{2} \\
R_{a j(\%)}^{2}=91.50 S_{y x(\%)}=4.75\end{array}$ & $\begin{array}{c}\beta_{0}=3.8328 \beta_{1}=-20.2667 \\
\beta_{2}=4.92 * 10^{-3} \beta_{3}=0.8301 \\
\beta_{4}=1.01 * 10^{-10}\end{array}$ \\
\hline
\end{tabular}

Where: $C=$ estimated consumption (1); $Q=$ driving distance $(\mathrm{km}) ; V=$ Average speed $\left(\mathrm{km} \mathrm{h}^{-1}\right) ; M=$ Liquid weight $(\mathrm{kg}) ; D$ $=$ time (min); $R_{a j(\%)}^{2}=$ Adjusted coefficient of determination; e $S_{y x(\%)}=$ Standard error for the estimate (\%).

Other researchers concluded that driving distance was the main variable to estimate cycle time and forest road transport costs (LEITE et al., 1993; KARAGIANNIS et al., 2012).

In addition to $R_{a j(\%)}^{2}$ and $S_{y x(\%)}$, we also analyzed the graphic of residues distribution to choose the equations to estimate fuel consumption. The graphics of the estimated error in the percentage of the original and logarithmic equations to estimate fuel consumption are shown in Figure 3.

According to the statistical results of $R_{a j(\%)}^{2}$, $S_{y x(\%)}$ and residue analysis, the precision of the model was verified (high $R_{a j(\%)}^{2}$ value and low $S_{y x(\%)-}$ value). Residue analysis graphics (Figure 3 ) represented the data of the truck's fuel consumption well: relative error values were lower than $50 \%$ for the underestimate and $50 \%$ for the overestimate.

When forest road transportation used a loaded truck, the estimative residues distribution of fuel consumption ranged from 35.0-70.0 1 trip $^{-1}$, values that were consistent with the coefficient of variance of fuel consumption for loaded trips. It was a good estimate for fuel consumption of the loaded truck. Both original and logarithmic equations presented overestimates of fuel consumption per trip around
60.01 trip $^{-1}$; the logarithmic equations produced overestimates of consumption of 38.01 trip $^{-1}$.

The unloaded trip presented more uniformity among the error dispersion of the estimated fuel consumption, values close to 401 had a weak tendency to be underestimated in the original and logarithmic equations.

Residue dispersion for total forest road transportation cycle underestimated a little the values of fuel consumption lower than 1101 for the adjusted equations. Consumption higher than 1351 showed values that were slightly underestimated. When the truck was used for forest road transportation, fuel consumption ranged from 70-150 1, with a homogeneous distribution.

It is important to notice that the estimated fuel consumption resulted from the variables collected, stored and transferred by the telemetric system installed in the truck. So, traditional studies of time and movement were not used to measure those variables. The use of such studies in addition to the telemetric system could improve the results with information of productive, auxiliary, accessory and unproductive (such as waiting in queues) time. 

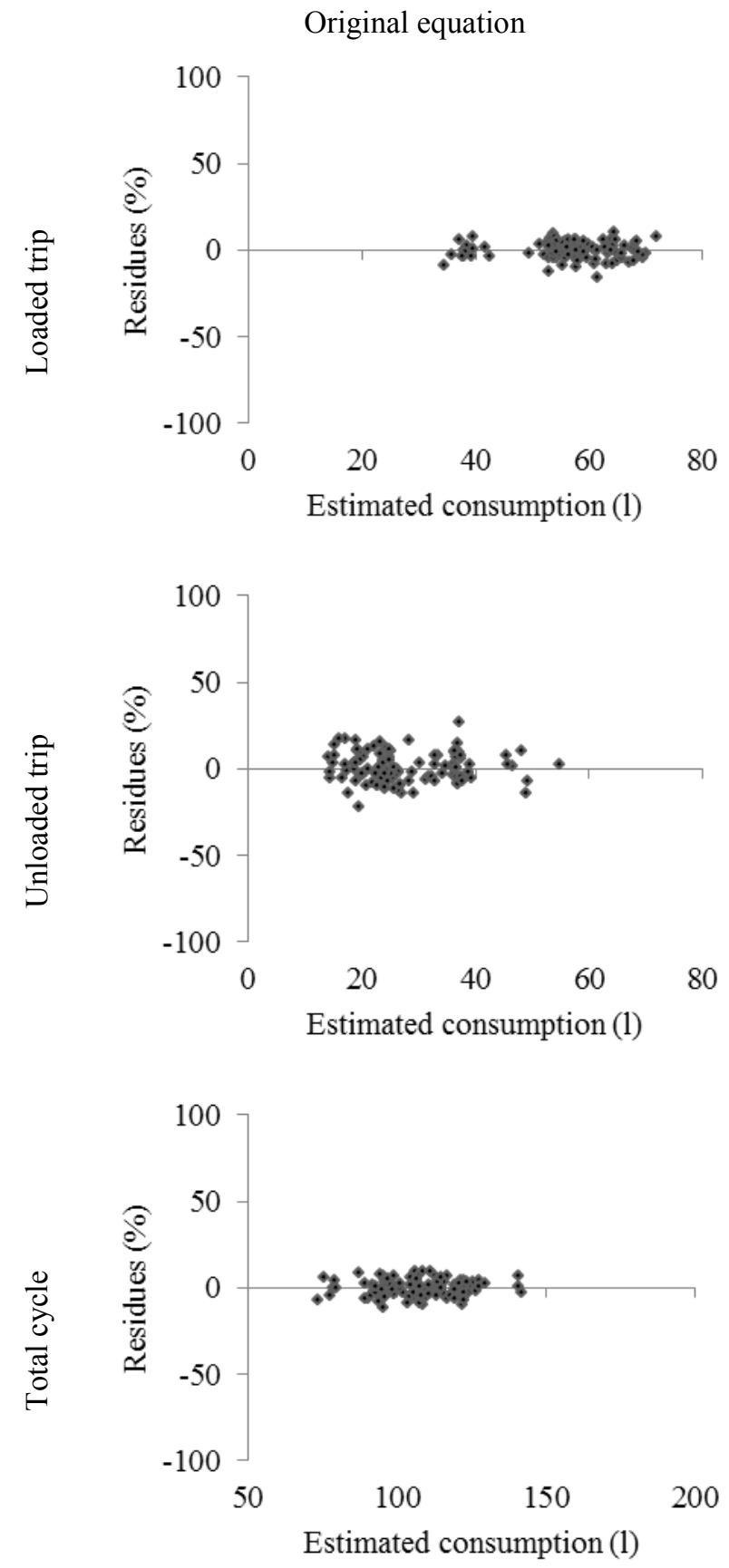
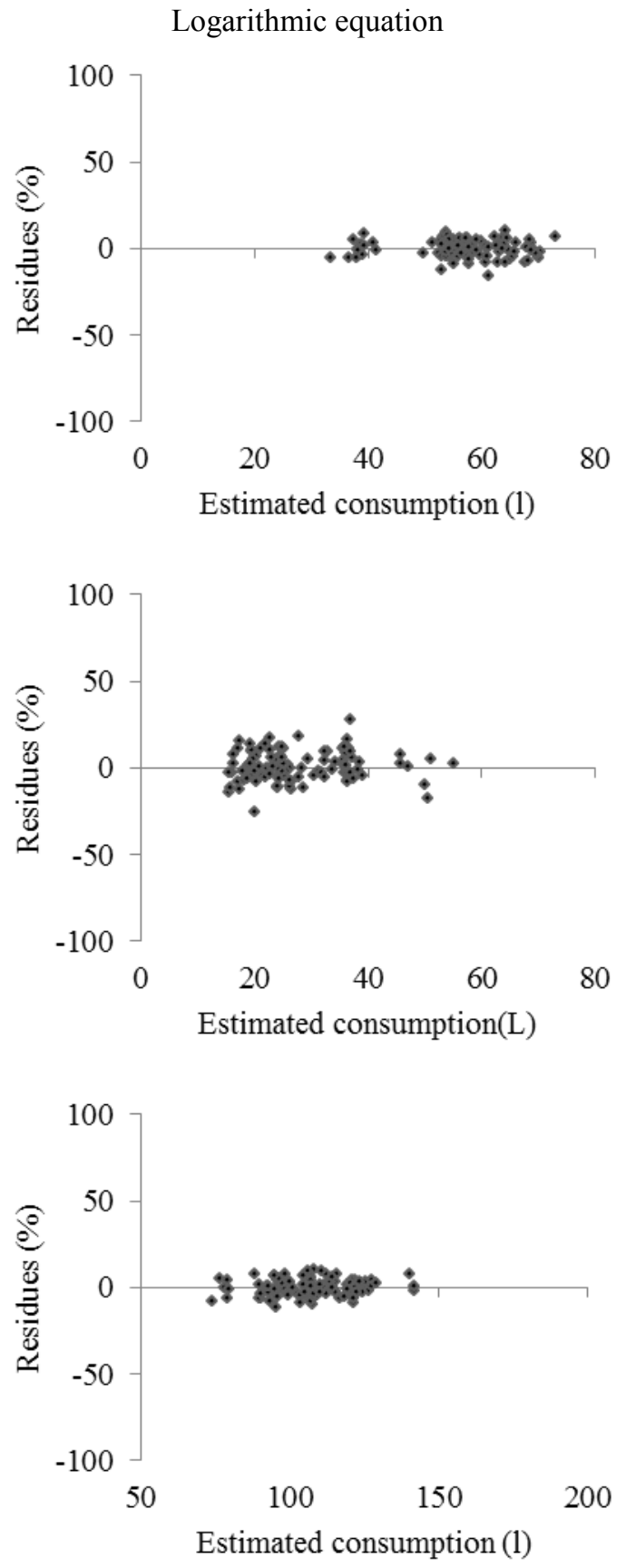

Figure 3. Residue distribution of estimated consumption for a truck.

\section{CONCLUSIONS}

The highest coefficient of variation found was for duration time, mainly for the work phase of displacement and loading, which makes evident the lack of trust and low availability of forest road transport. The unloading operation was quicker as it took place inside the industry.

Active transportation with the truck, loaded and unloaded trips, even with a small load compartment, allowed a faster operational speed (higher than $40 \mathrm{~km} \mathrm{~h}^{-1}$ ) and required a shorter time for loading and unloading.

The total transport cycle presented high duration values and a high coefficient of variation, as a reflection of intermediate activities, like slow loading and unloading, a loaded trip with high fuel consumption and, due to the specific requirement to forest load compartments, the necessity of unloaded trips.

The variable that most influenced the fuel consumption of the truck was the driving distance, followed by average speed and duration time.

The adjusted equations are statistically adequate to estimate fuel consumption as function of driving distance, liquid weight of transported load, average speed and duration time of loaded trip, unloaded trip and total forest road transportation 
cycle.

\section{REFERENCES}

ASSOCIAÇÃO BRASILEIRA DE PRODUTORES DE FLORESTAS PLANTADAS. Anual Estatístico ABRAF 2013, ano base 2012. Brasília, 2011. Disponível em: <http://www.abraflor.org.br/ estatisticas/ABRAF13/ABRAF13_BR.pdf $>$ Acesso em: 23/04/2012.

ALVES, R. T. et al. Análise técnica e de custos do transporte de madeira com diferentes composições veiculares. Revista Árvore, Viçosa, v. 37, n. 5, p. 897-904, 2013.

ARCE, J. E.; CARNIERI, C.; MENDES, J. B. Un sistema de programación del transporte forestal principal objetivando la minimización de costos. Investigación operativa, Rio de Janeiro, v. 8, n. 1, p. 51-61, 1999.

BARTHOLOMEU, D. B.; CAIXETA FILHO, J. V. Impactos econômicos e ambientais decorrentes do estado de conservação das rodovias brasileiras: um estudo de caso. Revista Economia e Sociologia Rural, Toledo, v. 46, n. 3, p. 703-738, 2008.

BRAGA, A. X. V.; SOUSA, M. A.; BRAGA, D. P. G. Custo operacional de caminhão bi-trem: aplicação atualizada e adaptada do método FAO/ América do Norte. Custo e agronegócio online, Recife, v. 7, n. 3, p. 40-60, 2011.

CONAW, P. L. Estatística. São Paulo, SP: Edgard Blucher, 1977. 264 p.

FIBRIA. Manual estrada segura, 2a edição, 2012. Disponível em: http://www.fibria.com.br/shared/ midia/publicacoes/

manual_fibria_estrada_segura_jan2012.pdf. Acesso em: 20/03/2014.

FREITAS, L. C. et al. Estudo comparativo envolvendo três métodos de cálculo de custo operacional do caminhão Bitrem. Revista Árvore, Viçosa, v. 28, n. 6, p. 855-863, 2004.

GOOGLE EARTH-MAPAS. Disponível em: <http:// mapas.google.com> Acesso em: 01/08/2014.

HOLZLEITNER, F.; KANZIAN, C. Analyzing time and fuel consumption in road transport of round wood with an onboard fleet manager. European Journal of Forest Research, Freising, v. 130, n. 2, p. 293-301, 2011.

\section{INSTITUTO NACIONAL DE METEOROLOGIA (INMET). Disponível em: <http:// www.inmet.gov.br/portal/index.php? $\mathrm{r}=\mathrm{bdmep} /$}

bdmep $>$ Acesso em: 30/07/2014.

KARAGIANNIS, E.; TSIORAS, P. A.; KARARIZOS, P. Timber trucking characteristics in Greece. Journal of Environmental Science and Engineering, El Monte, v. 1, n. 1, p. 1079-1086, 2012.

KLAN, R. et al. Utilização da Programação Linear na Otimização de Resultados de uma Empresa do Ramo de Transporte Rodoviário de Cargas. ABCustos Associação Brasileira de Custos, São Leopoldo, v. 5, n. 1, p. 1-22, 2010.

KLVAC, R. et al. Fuel consumption in timber haulage. Croatian Journal of Forest Engineering, Zagreb, v. 34, n. 2, p. 229-240, 2013.

LEITE, A. M. P; SOUZA, A. P.; MACHADO, C. C. Análise do ciclo de transporte de madeira para três tipos de caminhões. Revista Árvore, Viçosa, v. 17, n. 2, p. 190-201, 1993.

MACHADO, C. C. et al. Transporte rodoviário florestal. 2. ed. Viçosa, MG: Editora UFV, 2009. $217 \mathrm{p}$.

MORAIS, M. G. A. Colheita e transporte de madeira: terceirização $x$ verticalização das operações. 2012. 167 f. Dissertação (Mestrado em Ciências: Área de Concentração em Colheita e transporte de madeira: terceirização x verticalização das operações) - Universidade Federal de São Carlos, São Carlos, 2012.

NURMINEN, T.; HEINONEN, J. Characteristics and time consumption of timber trucking in Finland. Silva Fennica, Vantaa, v. 41, n. 3, p. 471-487, 2007.

PELISSARI, A. L. Silvicultura de precisão aplicada ao desenvolvimento de Tectona grandis L.f. na região Sul do Estado do Mato Grosso. 2012. 78 f. Dissertação (Mestrado em Ciências Florestais e Ambientais: Área de Concentração em Silvicultura e Manejo Florestal) - Universidade Federal do Mato Grosso, Cuiabá, 2012.

RIBEIRO, A. Modelagem e quantificação de nutrientes em povoamentos nativos de bracatinga 2012. 143 f. Dissertação (Mestrado em Engenharia Florestal: Área de Concentração em Manejo Florestal) - Universidade Federal do Paraná, Curitiba, 2012.

SCOLCOFO, J. R. B. Biometria florestal. Lavras, MG: UFLA/ FAEPE, 2005. 352 p.

SILVA, M. L. et al. Análise do custo e do raio econômico de transporte de madeira de reflorestamentos para diferentes tipos de veículos. 
Revista Árvore, Viçosa, v. 31, n. 6, p. 1073-1079, 2007.

SILVEIRA, G. L. et al. Avaliação de parâmetros de consumo de combustível do Tritem no transporte de madeira. Revista Árvore, Viçosa, v. 28, n. 1, p. 99106, 2004. 